\title{
The Gultivation of a Single Strain of Actinomyces israelii in a Simplified and Chemically Defined Medium
}

\author{
By A. O. CHRISTIE* and J. W. PORTEOUS \\ Department of Biological Chemistry, Marischal College, University of Aberdeen
}

(Received 4 September 1961)

\begin{abstract}
SUMMARY
Growth curves were determined for a single strain of Actinomyces israelii grown in systematic modifications of the partially defined medium of Howell \& Pine (1956). These determinations resulted in a progressive simplification of the Howell \& Pine medium and in the elucidation of a completely defined medium containing $335 \mu \mathrm{g}$. total $-\mathrm{N} / \mathrm{ml}$. instead of $948 \mu \mathrm{g}$. total- $\mathrm{N} / \mathrm{ml}$. in the original medium; the yield of organism was increased concomitantly from $55 \mu \mathrm{g}$. total- $\mathrm{N} / \mathrm{ml}$. of medium to $80 \mu \mathrm{g}$. total-N/ml. of medium. This simplified medium contained no ammonium sulphate, purine or pyrimidine bases but twenty amino acids (of which L-cysteine and L-tryptophan were found to be essential) and sixteen growth factors.
\end{abstract}

\section{INTRODUCTION}

Actinomyces israelii is a Gram-positive slow-growing anaerobic to micro-aerophilic organism forming small $(0.5-2.5 \mathrm{~mm}$. diameter) white coherent 'bread-crumb' or 'cauliflower' colonies which grow at the bottom of vessels of liquid media, leaving a clear supernatant medium at all stages of growth. Microscopic observation of pure cultures shows a non-sporing rebranching filamentous organism, the filaments seldom exceeding $1 \mu$ in diameter (Erikson, 1940, 1949; Erikson \& Porteous, 1955). The organism has a reputation for being difficult to isolate in pure culture and to maintain in laboratory culture for prolonged periods (see Erikson, 1940, 1953; Holm, 1948, 1951; Thomson \& Lovestedt, 1951). Rosebury, Epps \& Clark (1944) recommended cultivation in alternate complex undefined media. Other references to the use of complex media are given by Erikson \& Porteous (1953) who made the first successful attempt to maintain $A$. israelii in simpler media. They succeeded in obtaining good growth of 6 strains in serial subculture in a medium composed of equal volumes of broth $+1 \%(\mathrm{w} / \mathrm{v})$ casein hydrolysate $+0.5 \%(\mathrm{w} / \mathrm{v})$ glucose; 5 of these strains were trained to grow in continued subculture, though in diminished yield, in a medium composed of 99 volumes of $1 \%(w / v)$ casein hydrolysate + 1 volume of heart broth $+0.5 \%(\mathrm{w} / \mathrm{v})$ glucose. These authors could not replace the broth by chemically defined nutrients but showed that $A$. israelii could be maintained in these media for periods up to 2 years. They concluded that the 'short life, ... and at best lessened activity' of $A$. israelii reported by earlier workers who used more complex media might have been due to the presence in those media of growth inhibitory substances. Howell \& Pine (1956) reported a medium which

* Present address : Marine Biology Station, Menai Bridge, North Wales. 
was chemically defined except for the starch and possibly the oleic acid that it contained, and which supported the growth of 13 strains of anaerobic Actinomyces in serial subculture; 5 of the strains were typical of $A$. israelii as defined above. The present work is in continuation of that by Erikson \& Porteous (1953) and is based on the significant advance made by Howell \& Pine (1956). A preliminary account of the work has been published (Christie \& Porteous, 1959).

\section{METHODS}

Organism. The organism used was one of a collection of strains of Actinomyces israelii maintained by Dr Dagny Erikson and given to one of us (J.W.P.) in 1953. Cultures were freeze-dried at that time and maintained for various periods since 1956 in medium $S$ or medium $A$ of Erikson \& Porteous (1953).

Freeze-drying. Cultures were routinely freeze-dried at intervals of 3-6 months by using an LB 5 rotary dryer (Edwards High Vacuum, Ltd., Crawley, Sussex) and a suspension medium of equal volumes of ox-heart broth, horse serum (Burroughs Wellcome and Co., London) and $15 \%$ (w/v) glucose solution.

Reagents. All media and analytical solutions were made up in distilled water unless stated to the contrary. The following compounds were used in preparing media: $\mathrm{KH}_{2} \mathrm{PO}_{4}, \quad\left(\mathrm{NH}_{4}\right)_{2} \mathrm{SO}_{4}, \mathrm{MgSO}_{4} \cdot 7 \mathrm{H}_{2} \mathrm{O}, \mathrm{Na}$ acetate $.2 \mathrm{H}_{2} \mathrm{O}, \mathrm{CaCl}_{2} \cdot 6 \mathrm{H}_{2} \mathrm{O}$,

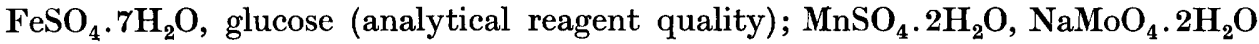
(reagent quality); casein hydrolysate (vitamin-free for biological assay; batch 1650; Allen and Hanburys, Ltd.); $p$-aminobenzoic acid, oleic acid, haemin (British Drug Houses, Ltd.); folic acid, pimelic acid, pyridoxal. $\mathrm{HCl}$, pyridoxamine. $\mathrm{HCl}$, thiamine. $\mathrm{HCl}$, thioctic acid, purine and pyrimidine bases (L. Light and Co. Ltd.); biotin, calcium pantothenate, inositol, nicotinic acid, nicotinamide (Roche Products Ltd., Welwyn Garden City, Hertfordshire); glutathione (Distillers Company Ltd.); coenzyme A (70\% assay; Sigma Chemical Company; agents G. T. Gurr Ltd., London); vitamin $\mathrm{B}_{12}$ (crystalline; Glaxo Laboratories); the amino acids were the best quality available, and, except for L-cysteine. $\mathrm{HCl}$, were not further purified.

Measurement of $p H$ values. A Model $30 \mathrm{pH}$ meter (Electronic Instruments Ltd., Richmond, Surrey) was used except for measurements on $0.1 \mathrm{ml}$. samples of inoculated media which were made with a capillator indicator set (British Drug Houses Ltd., Poole, Dorset).

Sterilization. All glassware was autoclaved at $120^{\circ}$ for $20 \mathrm{~min}$. Maintenance media were heat sterilized and dispensed as described by Erikson \& Porteous (1953); chemically defined media, or component parts thereof, were sterilized by filtration through a P11 porcelain filter (Baird and Tatlock Ltd., London) or through a cellulose acetate filter membrane (A. Gallenkamp and Co. Ltd., London).

Culture vessels. Unless otherwise stated, rimless Pyrex tubes $(12 \times 75 \mathrm{~mm}$.) containing $2 \mathrm{ml}$. liquid medium were used. Small volumes of all media were dispensed as described by Erikson \& Porteous (1953).

Anaerobiosis. Stock cultures were maintained under hydrogen in an anaerobic jar (Erikson \& Porteous, 1953). Experimental media were sealed in individual culture vessels with a layer of sterile liquid paraffin.

Inoculation technique. All inoculations were made with Pasteur pipettes. In all quantitative growth experiments, preparation of inoculum and quantitative inoculation were carried out as described by Christie \& Porteous (1960). In the 
routine maintenance of stock cultures, the larger colonies in tubes of liquid medium were broken up, so far as possible, with the tip of a Pasteur pipette and four to eight of the resulting small clumps transferred to each $2 \mathrm{ml}$. volume of fresh medium. Cultures were incubated at $37^{\circ}$.

Tests for culture purity. All cultures were tested periodically as follows. (i) Small fragments of colonies were stained with $0.1 \%(\mathrm{w} / \mathrm{v})$ methylene blue and examined microscopically under a cover-slip with an oil-immersion objective. Cultures were rejected when they showed any signs of contamination or when they failed to accord with the description given in the introductory paragraph of this paper. (ii) Replicate tubes of medium were inoculated and incubated aerobically; cultures were rejected when growth occurred in a second aerobic subculture (Erikson \& Porteous, 1955). (iii) Duplicate nutrient agar plates were inoculated by spreading fragments of colonies over the agar surfaces; both plates were incubated at $37^{\circ}$, one aerobically, the other under hydrogen. Cultures were rejected when the aerobic plate showed any growth which survived a second aerobic subculture or when the anaerobic plate failed to produce typical Actinomyces israelii colonies only, i.e. abruptly raised, nodular colonies (Erikson \& Porteous, 1953, 1955). (iv) Biphasic agargel media were inoculated as described by Erikson \& Porteous (1955); cultures were retained only when the colonies which developed in these media were discrete, compact, nodular, and free from any 'tailing'. Medium S of Erikson \& Porteous (1953) was used in all the above culture tests.

Analytical techniques. (i) Growth curves were determined by inoculating replicate tubes of liquid medium with Actinomyces israelii in the manner already described. At appropriate times after inoculation and incubation, two pairs of tubes were withdrawn; colonies were quantitatively removed from a pair of tubes by Pasteur pipette into an $18 \times 150 \mathrm{~mm}$. Pyrex test tube, the colonies allowed to sediment in the tube and then washed twice by sedimentation in a total of $25 \mathrm{ml}$. distilled water. Colonies from the other pair of culture tubes were treated in the same way and the duplicate washed samples analysed for total-N content; all growth yields quoted are the average of two such determinations expressed as $\mu \mathrm{g}$. total- $\mathrm{N}$ content of the colonies harvested from $1 \mathrm{ml}$. medium, after correction for the total- $\mathbf{N}$ content of the corresponding inoculum. The remaining medium from each pair of culture tubes was filtered through Whatman No. 1 filter paper to remove any liquid paraffin and the duplicate filtrates taken for analysis. All results quoted are the average of the duplicate determinations expressed as the quantity of the compound determined per ml. medium.

(ii) Total- $\mathrm{N}$ determinations on harvested colonies and on media were done in duplicate as described by Christie \& Porteous (1960), using the digestion apparatus described by Porteous (1960).

(iii) $\alpha$-Amino-N was determined by the method of Pope \& Stevens (1939) on 1-5 ml. samples of medium.

(iv) Ammonia- $\mathrm{N}$ was determined by Conway's method (1950), water blanks and ammonium sulphate standards being included with each set of determinations. 


\section{RESULTS}

Media; terminology. All experimental media were derived from that published by Howell \& Pine (1956) by progressive elimination of certain components. The composition of the Howell \& Pine medium, referred to hereafter as medium HP, is shown in Tables 1 and 2; progressive modifications of this medium are designated HP1, HP2, etc. Any component omitted from a member of this series of media was omitted from all subsequent members of the series. Inoculation into a new

Table 1. Composition and preparation of medium HP (Howell \& Pine, 1956)

1. Major salts

$\mathrm{KH}_{2} \mathrm{PO}_{4}$

$\mathrm{MgSO}_{4} \cdot 7 \mathrm{H}_{2} \mathrm{O}$

$\mathrm{CaCl}_{2} \cdot 2 \mathrm{H}_{2} \mathrm{O}$

$\mathrm{CH}_{3} \mathrm{COONa}_{2} 2 \mathrm{H}_{2} \mathrm{O}$

2. Minor salts

$\mathrm{FeSO}_{4} \cdot 7 \mathrm{H}_{2} \mathrm{O}$

$\mathrm{MnSO}_{4} \cdot 2 \mathrm{H}_{2} \mathrm{O}$

3. Glucose

$\mathrm{NaMoO}_{4} \cdot 2 \mathrm{H}_{2} \mathrm{O}$

4. $\left(\mathrm{NH}_{4}\right)_{2} \mathrm{SO}_{4}$

5. Cysteine. $\mathrm{HCl}$

6. Glutathione

7. L-Asparagine

8. L-Tryptophan

9. Purines and pyrimidines

Adenine sulphate

Guanine hydrochloride

Uracil

Xanthine

Thymine

10. (a) Casein hydrolysate (vitamin free); or (b) amino acids as listed in Table 4, column $A$

11. Vitamins and growth factors as listed in Table 2

12. Purified potato starch

\begin{tabular}{|c|c|}
\hline \multicolumn{2}{|c|}{ per litre } \\
\hline (g.) & (mg.) \\
\hline $15 \cdot 0$ & - \\
\hline- & $200 \cdot 0$ \\
\hline- & $20 \cdot 0$ \\
\hline - & $300 \cdot 0$ \\
\hline 一 & 4.0 \\
\hline - & $0 \cdot 15$ \\
\hline- & $0 \cdot 15$ \\
\hline $10 \cdot 0$ & - \\
\hline 1.0 & - \\
\hline 1.0 & - \\
\hline- & $500 \cdot 0$ \\
\hline- & $100 \cdot 0$ \\
\hline - & $40 \cdot 0$ \\
\hline- & $20 \cdot 0$ \\
\hline- & $20 \cdot 0$ \\
\hline - & $20 \cdot 0$ \\
\hline- & $20 \cdot 0$ \\
\hline- & $20 \cdot 0$ \\
\hline $4 \cdot 0$ & - \\
\hline- & - \\
\hline & $500 \cdot 0$ \\
\hline
\end{tabular}

A solution of the above components, less the starch, was adjusted with $2 \mathrm{~N}-\mathrm{KOH}$ to the required $\mathrm{pH}$ value (7.2 in the present work) before dilution to a known volume with water and sterilization by filtration. Heat sterilized starch solution was then added to give the desired starch concentration and to dilute other components to the required concentration.

\section{Table 2. Growth factor components of medium HP (Table 1)}

\section{Growth factors}

$p$-Aminobenzoic acid

Thiamine. $\mathrm{HCl}$

Riboflavin

Nicotinic acid

Nicotinamide

Pyridoxal . HCl

Pyridoxamine. $\mathrm{HCl}$

Ca pantothenate

Inositol

Oleic acid

Coenzyme A (70 \% assay)

$$
\text { (mg./l.) }
$$

DL-thioctic acid

Biotin

Pimelic acid

Haemin

Folic acid

Vitamin $\mathbf{B}_{12}$

Citrovorum factor
( $\mu \mathrm{g} . / 1$.

100

100

100

200

500

1

100 
member of the series of experimental media was always made from a mother culture in the simplest available medium of the series.

Selection of test organism. All eleven organisms available were isolated from human actinomycotic lesions. All strains were microscopically, macroscopically and physiologically typical of Actinomyces israelii when grown in medium $\mathbf{S}$ of Erikson \& Porteous (1953). Two strains failed to grow in medium HP 1 (medium HP, less citrovorum factor and less coenzyme A; Tables 1, 2). Three other strains survived only a few serial subcultures in this medium. The remaining 6 strains survived serial subculture in medium HP1. The techniques available for preparing uniform inocula of $A$. israelii (Christie \& Porteous, 1960) and for measuring the growth of the inoculum (see: Methods, Analytical techniques) restricted the number of strains which could be investigated quantitatively and exhaustively. Strain Wills was selected as apparently representative of the 6 strains available which would grow in medium HP1; all results presented below refer to strain Wills of $\boldsymbol{A}$. israelii.

Optimum initial $p H$ value of the medium. Good growth occurred when the initial $\mathrm{pH}$ value of medium HP1 lay between $7 \cdot 0$ and $7 \cdot 6$; outside these limits the yield of organism decreased rapidly until at an initial $\mathrm{pH}$ of $6 \cdot 6$ or $7 \cdot 8$ the inoculum failed to grow. In further experiments all media were adjusted initially to $\mathrm{pH} \mathbf{7 \cdot 2}$.

\section{Change in the $p H$ value of the medium during growth of Actinomyces israelii}

Preliminary experiments showed (Fig. 1 ) that $(a)$ the $\mathrm{pH}$ value of medium HP1 decreased rapidly from $\mathrm{pH} 7 \cdot 1$ to $5 \cdot 5$ during the period when the increase in cell nitrogen was rapid with respect to time (analogous to the logarithmic growth phase of simple bacteria); $(b)$ after growth ceased, the $\mathrm{pH}$ value of the medium continued to decrease to a limiting value of $\mathrm{pH} 5 \cdot 0$. These observations were found to be valid in several subsequent modifications of the medium; colonies harvested during the period of most rapid growth ( $\mathrm{pH}$ of medium $=7 \cdot \mathbf{1}$ to $6 \cdot \mathbf{1}$ ) continued to grow at the same rate when subcultured to a medium of the same initial composition

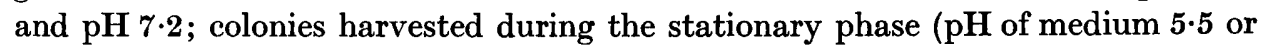
less) showed a lag of 30-60 hr. when subcultured to fresh medium of the same initial composition and $\mathrm{pH}$ 7.2. $\mathrm{pH}$ measurements were therefore routinely used to determine the approximate growth phase of cultures, particularly of those intended as sources of inocula for quantitative growth experiments designed to measure the response of Actinomyces israelii to major components of medium HP.

\section{Progressive simplification of the Howell \& Pine medium}

In all experiments reported hereafter, glucose and the major and minor salts were retained in experimental media at the concentrations given in Table 1 (items 1, 2 and 3); coenzyme $\mathbf{A}$ and citrovorum factor were omitted from all media and the remainder of the growth factors (Table 1, item 11) retained at the concentrations shown in Table 2 . Table 3 shows the contribution of the various major components (see Tables 1, 2) to the total-N content of medium HP1.

The requirements for ammonium sulphate, L-cysteine and glutathione in the growth medium for Actinomyces israelii Wills strain were investigated in turn; the requirement for purine and pyrimidine bases was then investigated before modifying the amino acid concentration of the resulting medium. In these investigations 
growth curves were determined in the manner described. With an exception (noted below) all inocula were taken from a mother culture in the rapid growth phase. All growth curves for nutritionally adequate media were of the general form shown in Fig. 1, i.e. a lag of 20-30 hr. followed by a period of rapid growth, with the culture entering the stationary phase between 70 and $90 \mathrm{hr}$. after inoculation.

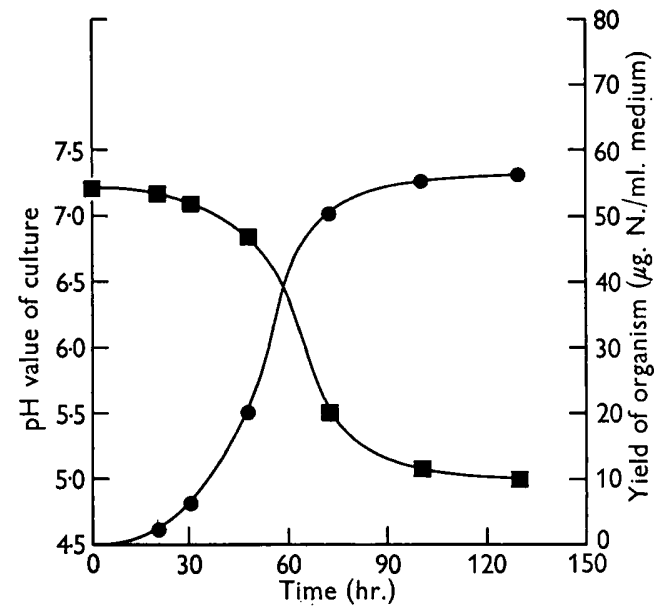

Fig. 1. Changes in the pH value of medium HP1 (Table 6) during growth of the Wills strain of Actinomyces israelii at $37^{\circ}$ under liquid paraffin seals. growth.

The successive modifications to medium HP1 and the maximum growth obtained in the modified media are shown in Table 6. Five concentrations of ammonium sulphate were tested in modifications of medium HP1. Since the presence or absence of ammonium sulphate did not affect the growth rates or yields of organism this salt was omitted from medium HP1 to give medium HP2 which was then modified to contain L-cysteine at six concentrations within the range $0-1000 \mu \mathrm{g} . / \mathrm{ml}$. No growth was obtained when L-cysteine was omitted; at initial concentrations between 20 and $100 \mu \mathrm{g}$. cysteine/ml. there was a roughly linear growth response and maximal growth was obtained with an initial L-cysteine concentration of $200 \mu \mathrm{g} . / \mathrm{ml}$.

Table 3. Calculated total- $N$ content of the major nitrogen-containing components of medium HP (Table 1)

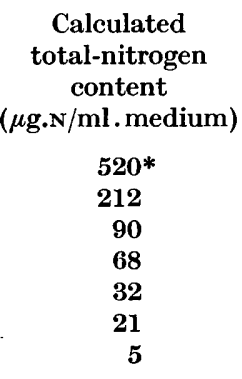

Total : 948

* This value determined experimentally on a separate stock solution of casein hydrolysate. 
Medium HP2 modified to contain cysteine at this concentration was termed medium HP3, with a glutathione content of $500 \mu \mathrm{g} . / \mathrm{ml}$. In initial experiments medium HP3 was modified to contain $0,100,250$ and $500 \mu \mathrm{g}$. glutathione $/ \mathrm{ml}$. The corresponding growth curves are shown in Fig. 2. In further experiments only the first and last of the above modifications of medium HP3 were used; normal growth curves were obtained which are also shown in Fig. 2. Both sets of results showed that the final cell yield was independent of the initial glutathione concentration. In the initial experiments there was a pronounced lag which was most marked in the absence of glutathione from the medium; the inocula in this experiment were taken from a culture in the stationary phase $(\mathrm{pH}$ of medium at harvest $=5 \cdot 0)$, but the longest lag was greater than could be accounted for solely by the use of stationary phase inocula. In the second experiment there was no apparent lag whether glutathione was present or absent; the inocula in this instance were taken from a culture in its most rapid phase of growth ( $\mathrm{pH}$ of medium at harvest $=6 \cdot 6)$. Although there did not seem to be a specific requirement for glutathione it was retained at a concentration of $100 \mu \mathrm{g} . / \mathrm{ml}$. for further experiments and medium HP3 modified in this way became medium HP 4 .

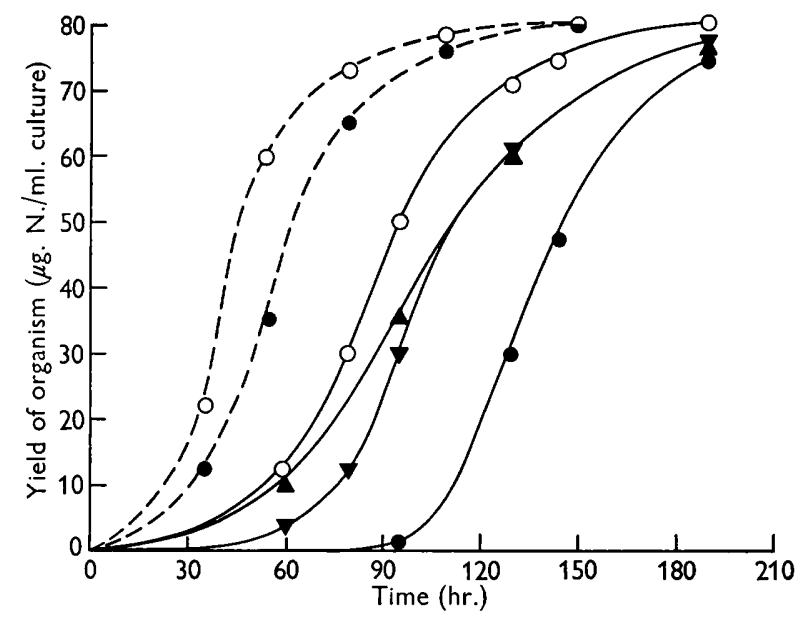

Fig. 2. Growth of the Wills strain of Actinomyces israelii at $37^{\circ}$ under liquid paraffin seals in $2 \mathrm{ml}$. volumes of medium HP3 (Table 6) modified to contain various initial concentrations of glutathione $(\mu \mathrm{g} . / \mathrm{ml}$. medium): $\bigcirc-\bigcirc, 500$ (medium HP 3); $\mathbf{\Delta}-\mathbf{\Delta}$, $250 ; \nabla-\nabla, 100$ (medium HP4, Table 6); $-0,0$. Growth of an inoculum taken from a stationary phase mother culture is indicated by a full line; growth of an inoculum taken from a rapidly growing mother culture is indicated by a broken line.

Omission of the purine and pyrimidine bases from medium HP4 did not affect the yield of organism and gave medium HP 5 which became the basal medium for investigation of the amino acid requirements.

Howell \& Pine (1956) supplemented their casein hydrolysate medium (Tables 1, 2) with $\mathrm{L}_{\mathrm{L}}$-asparagine and with L-tryptophan. Omission of L-asparagine from medium HP 4 decreased the yield of organism by $15 \%$. When L-tryptophan was omitted from medium HP4 no growth occurred. Both these amino acids were therefore retained at the original concentration in all subsequent media.

Howell \& Pine (1956) replaced the casein hydrolysate in their medium by an 
amino acid mixture (item $10 \mathrm{~b}$, Table 1) which was supposed to simulate the concentrations of amino acids supplied by the casein hydrolysate. In the experiments of Howell \& Pine replacement of their casein hydrolysate by this amino acid mixture had no significant effect on the rate of growth or on the final yields of organism with the three organisms they tested, one of which was identified as Actinomyces israelii, one as probably $A$. israelii and one as $A$. naeslundii. Replacement of the casein hydrolysate of medium HP5 by the amino acid mixture used by Howell \& Pine gave medium HP6/A in which the yield of organism was only $65 \%$ of that in the casein hydrolysate medium HP 5 (Table 6). It appeared that the amino acid mixture did not simulate the casein hydrolysate used in the present work. In a comparative experiment medium HP 5 was therefore modified by substituting two amino acid mixtures (' $A$ ' and ' $B$ ', Table 4) for the casein hydrolysate to give media HP6/A and HP6/B, differing in the proportions of the amino acids present but essentially identical in their total- $N$ content. Concurrent experiments with medium HP5 had shown that starch (Table 1) was not required for the growth of A. israelii Wills strain. Starch was therefore omitted from media HP6/A and HP6/B. The yield of organism obtained in medium HP6/A was only 74\% of that obtained in medium HP 6/B, where the yield was $87 \%$ of that in the casein hydrolysate medium HP5 (Table 6). Medium HP6 containing amino acid mixture ' $B$ ' (Table 4) was therefore adopted for further experiments.

Further experiments showed that medium HP7 (medium HP6/B modified to contain glutamic acid at a concentration of $100 \mu \mathrm{g} . / \mathrm{ml}$. and each of the other amino acids of mixture ' $\mathrm{B}$ ' (Table 4) at a concentration of $50 \mu \mathrm{g} . / \mathrm{ml}$.) would just support

Table 4. The composition of two amino acid mixtures $(A$ and $B)$ used in the preparation of the completely defined media HP6|A and HP6|B (Table 6), together with the total- $N$ contribution of the amino acids to the media. Amino acid mixture $(A)$ was that used by Horvell \& Pine (1956)

\begin{tabular}{|c|c|c|c|c|}
\hline \multirow[b]{2}{*}{ Amino acid } & \multicolumn{2}{|c|}{$\begin{array}{l}\text { Concentration in the medium } \\
(\mu \mathrm{g} . / \mathrm{ml} .)\end{array}$} & \multicolumn{2}{|c|}{$\begin{array}{l}\text { Total-N contribution to } \\
\text { the medium } \\
(\mu \mathrm{g} . \mathrm{N} / \mathrm{ml} .)\end{array}$} \\
\hline & (A) & (B) & (A) & (B) \\
\hline Glycine & 20 & 200 & $3 \cdot 7$ & $37 \cdot 3$ \\
\hline L-Álanine & 220 & 200 & $34 \cdot 6$ & $31 \cdot 4$ \\
\hline DL-Serine & 308 & 200 & $41 \cdot 0$ & $26 \cdot 7$ \\
\hline L-Threonine & 152 & 200 & $17 \cdot 9$ & $23 \cdot 5$ \\
\hline L-Leucine & 388 & 200 & $41 \cdot 5$ & $21 \cdot 4$ \\
\hline L-Isoleucine & 252 & 200 & $26 \cdot 9$ & $21 \cdot 4$ \\
\hline vL-Valine & 260 & 200 & $31 \cdot 1$ & $24 \cdot 0$ \\
\hline L-Glutamic acid & 932 & 1000 & $88 \cdot 8$ & $95 \cdot 2$ \\
\hline L-Aspartic acid & 244 & 200 & $25 \cdot 7$ & $21 \cdot 0$ \\
\hline L-Lysine & 304 & 200 & $58 \cdot 3$ & $38 \cdot 4$ \\
\hline L-Arginine & 172 & 200 & $55 \cdot 3$ & $64 \cdot 0$ \\
\hline L-Histidine & 84 & 200 & $22 \cdot 8$ & $54 \cdot 2$ \\
\hline L-Proline & 320 & 200 & $39 \cdot 0$ & $24 \cdot 4$ \\
\hline L-Hydroxyproline & 12 & 200 & $1 \cdot 3$ & $21 \cdot 4$ \\
\hline L-Phenylalanine & 200 & 200 & $17 \cdot 0$ & $17 \cdot 0$ \\
\hline L-Tyrosine & 268 & 200 & $20 \cdot 7$ & $15 \cdot 5$ \\
\hline L-Tryptophan* & 48 & - & 6.5 & - \\
\hline DL-Methionine & 136 & 200 & $12 \cdot 8$ & $18 \cdot 8$ \\
\hline Total: & 4320 & 4200 & $544 \cdot 9$ & $555 \cdot 6$ \\
\hline
\end{tabular}


growth of Actinomyces israelii strain Wills. Earlier attempts to obtain a nitrogen balance sheet for the growth of the organism in medium HP1 (Fig. 1) failed because of the low yields of organism relative to the nitrogen content of the medium (Table 6). The attempt was repeated for growth in medium HP7 with the results shown in Table 5 . The ammonia- $\mathrm{N}$ content of the medium (arising from the ammonia used to dissolve haemin in preparing the medium) was essentially unaltered at the end of the growth period. The yield of organism balanced the decrease in the $\alpha$-amino-N content of the medium and this decrease accounted for $97 \%$ of the decrease in the total- $\mathrm{N}$ content of the medium.

Table 5. Nitrogen balance after growth of the Wills strain of Actinomyces israelii for 6 days at $37^{\circ}$ under liquid paraffin seal in medium HP7 (Table 6)

\begin{tabular}{|c|c|c|c|c|}
\hline \multirow[b]{3}{*}{ Organism (total-N) } & \multirow{2}{*}{$\begin{array}{l}\text { Calculated } \\
0 \text { days }\end{array}$} & \multicolumn{2}{|c|}{ Determined } & \multirow[b]{2}{*}{$\begin{array}{c}\text { Increase or } \\
\text { decrease }\end{array}$} \\
\hline & & & $\mu \mathrm{g} . \mathrm{N} / \mathrm{ml}$. medium & \\
\hline & - & 0 & 29 & +29 \\
\hline Medium (total-N) & 182 & 179 & 149 & $-\mathbf{3 0}$ \\
\hline Medium ( $\alpha$-amino-N) & 130 & 122 & 93 & -29 \\
\hline Medium (ammonia-N) & $\mathbf{0}$ & 2 & $\mathbf{2 \cdot 5}$ & +0.5 \\
\hline
\end{tabular}

The absolute yield of organism in medium HP7 was however low. Medium HP6/B was therefore further modified to contain half the concentration of each of the amino acids in mixture ' $\mathrm{B}$ ' (Table 4). A yield of organism equivalent to $80 \mu \mathrm{g}$. total-N/ml. medium was obtained after 6 days incubation in this medium HP 8 containing initially $335 \mu \mathrm{g}$. total-N/ml. medium. This may be compared (Table 6) with the yield equivalent to $55 \mu \mathrm{g}$. total-N/ml. of medium HP1 which contained initially $948 \mu \mathrm{g}$. total-N/ml. (Fig. 1, Table 3).

\section{Miscellaneous experiments with modifications of medium $\mathbf{H P}$}

In an experiment reported above a partial requirement for L-asparagine in the nutrition of $\boldsymbol{A}$. israelii strain Wills was noted. Addition of L-glutamine to medium HP 5 (Table 6) at 100, 200 and $300 \mu \mathrm{g}$. $/ \mathrm{ml}$. had no significant effect on growth rates or on yields of organism. Addition of ascorbic acid at $200 \mu \mathrm{g} . / \mathrm{ml}$. to medium HP4 (Table 6) made no significant difference to the yield of organism although a slight decrease in the length of the lag phase was noted.

\section{DISCUSSION}

The most significant recent advance in our knowledge of the nutritional requirements of Actinomyces israelii and related organisms was made by Howell \& Pine (1956) who showed that a complex but essentially chemically defined medium, originally devised for the culture of Histoplasma capsulatum, also supported several Actinomyces species. By determining the growth curves for a single strain (Wills) of $\boldsymbol{A}$. israelii in systematic modifications of the medium of Howell \& Pine it has now been possible to assess the nutritional value of the major nitrogen-containing components of the original medium. It has been found that all the ammonium sulphate and the purine and pyrimidine bases of the original medium may be 
Table 6. Cumulative modifications to the Howell \& Pine (1956) medium, together with the calculated total- $N$ content of each medium and the yields of Wills strain of Actinomyces israelii grown in each medium

Medium and cross-reference

HP (Tables 1, 2, 3)

HP 1 ('Tables 1, 2, 3)

HP2 (Table 3)

HP3 (Table 3)

HP4 (Table 3, Fig. 2)

HP5 (Table 3)

HP 6/A (Tables 1, 3, 4)

HP 6/B (Table 4)

HPr (Tables 4, 5)

HP 8 (Table 4)
Cumulative modifications to medium HP

Coenzyme $\mathbf{A}$ and citrovorum factor omitted

$\left(\mathrm{NH}_{4}\right)_{2} \mathrm{SO}_{4}$ omitted

L-cysteine. $\mathrm{HCl}$ concentration decreased to $1 / 5$ concentration in medium $\mathbf{H P}$

Glutathione concentration decreased to $1 / 5$ concentration in medium $\mathbf{H P}$

Purine and pyrimidine bases omitted

Starch omitted; casein hydrolysate replaced by amino acid mixture

(A)

As HP6/A but amino acid mixture (A) replaced by amino acid mixture (B)

Glutamic acid concentration decreased to $1 / 10$ and concentrations of other amino acids of mixture (B) decreased to $1 / 4$ the concentrations in medium HP 6/B

Concentration of all amino acids of mixture (B) decreased to $1 / 2$ the concentrations in medium HP 6/B

$\begin{array}{cc}\begin{array}{c}\text { Calculated } \\ \text { total-nitrogen } \\ \text { content of }\end{array} & \begin{array}{c}\text { Maximum } \\ \text { yield of } \\ \text { organism }\end{array} \\ \text { medium } & \text { as cell-N } \\ (\mu \mathrm{g} . \mathrm{N} / \mathrm{ml} . & (\mu \mathrm{g} . \mathrm{N} / \mathrm{ml} .) \\ \text { medium }) & \text { medium })\end{array}$

948

948

55

736

65

664

75

610

80

578

80

603

52

613

70

182

29

335

80

omitted. The initial concentration of cysteine in the medium was decreased to onefifth of its original concentration without affecting the final yield of organism and under certain circumstances glutathione could be omitted. Casein hydrolysate was successfully replaced by a mixture of twenty amino acids. Of the eighteen growth factors present in the original Howell \& Pine medium, coenzyme $\mathbf{A}$ and citrovorum factor were found to be unnecessary for the cultivation of the Wills strain of $A$. israelii. These modifications to the original medium, together with the elimination of starch from it, led to the formulation of a simplified defined medium (HP6/B, Table 6) which has supported the Wills strain of $A$. israelii in continued subculture over a period of 6 months. The medium contains approximately $65 \%$ of the total-N of the Howell \& Pine medium and consistently gives a better yield of the organism (Table 6). Less extensive tests have shown that the Wills strain of $A$. israelii can survive at least five serial cultures in medium HP 8 (Table 6), containing only $35 \%$ of the total-N of medium HP, without diminution in the growth yield. Of the twenty amino acids present in media HP6/B and HP8, cysteine and tryptophan are essential for the Wills strain of $\boldsymbol{A}$. israelii. 
The results depicted in Fig. 2 indicated that glutathione was not an essential component of the growth medium but that this compound was effective in decreasing the prolonged lag exhibited when an inoculum taken from a mother culture which had entered the stationary phase was used. Inocula taken from a rapidly developing mother culture gave no lag whether or not glutathione was present in the medium. Glutathione might fulfil either or both of two functions; it might act as a redox buffer $\left(E_{0}^{\prime}=40 \mathrm{mV} . ; \mathrm{pH} 7\right)$ and/or as a nutrient for growth. Addition of ascorbic acid $\left(E_{0}^{\prime}=50 \mathrm{mV} . ; \mathrm{pH} 7\right)$ to medium HP4 (Table 6) containing $100 \mu \mathrm{g}$. glutathione/ ml. did slightly decrease the lag in a controlled experiment. This result suggests that the redox potential of the medium might be critical especially in the initial growth phase of Actinomyces israelii strain Wills but does not prove that glutathione acts exclusively or even mainly as a redox buffer. Glutathione may be required for metabolism within the cell and the actively growing organism is perhaps able to synthesize glutathione at a rate adequate for continued rapid growth, while the organism taken from a stationary phase culture is perhaps unable initially to synthesize the peptide sufficiently fast for rapid growth. It may be significant that $\mathrm{L}$-cysteine proved to be an essential amino acid in the nutrition of the organism and it may be recalled that Erikson \& Porteous (1953) emphasized the need for frequent subcultivation in the successful maintenance of $A$. israelii.

Our thanks are due to the Department of Scientific and Industrial Research for a Research Studentship awarded to one of us (A.O.C.). Vitamin $\mathbf{B}_{12}$ was a gift from Glaxo Laboratories Ltd.; the glutathione was part of a generous gift to Professor W. O. Kermack from the Distillers Company Ltd. We are grateful to Dr F. A. Robinson (Allen and Hanbury Ltd.) for help in obtaining a supply of suitable casein hydrolysate. Dr Dagny Erikson is acknowledged for her past guidance and for the generous gift of her collection of strains of Actinomyces israelii. We also thank Professor Kermack for his continued interest in the work and for helpful discussions during its progress.

\section{REFERENCES}

Conway, E. J. (1950). Microdiffusion analysis and volumetric error, 3rd ed., p. 95. London: Crosby Lockwood and Son, Ltd.

Christie, A. O. \& Porteous, J. W. (1959). The nutritional requirements of Actinomyces israelii. Biochem. J. 73, 47 P.

Christie, A. O. \& Porteous, J. W. (1960). A technique for obtaining uniform inocula of Actinomyces israelii. J. gen. Microbiol. 23, 261.

Erikson, D. (1940). Pathogenic anaerobic organisms of the Actinomyces group. Spec. Rep. Ser. med. Res. Coun., Lond. no. 240.

Erikson, D. (1949). The morphology, cytology and taxonomy of the actinomycetes. Annu. Rev. Microbiol. 3, 23.

Erikson, D. (1953). Variation of mycelial pattern in sporogenous and asporogenous Actinomycetes. 6th Congr. int. Microbiol. Symp. Actinomycetales, p. 102.

Erikson, D. \& Porteous, J. W. (1953). The cultivation of Actinomyces israelii in a progressively less complex medium. J. gen. Microbiol. 8, 464.

Erikson, D. \& Porteous, J. W. (1955). Commensalism in pathogenic anaerobic Actinomyces cultures. J. gen. Microbiol. 13, 261.

HoLM, P. (1948). Some investigations into the penicillin sensitivity of human pathogenic actinomycetes. Acta path. microbiol. scand. 25, 376.

Holm, P. (1951). Studies on the aetiology of human actinomycosis. II. Do the 'other microbes' of actinomycosis possess virulence? Acta path. microbiol. scand. 28, 391. 
Howeld, A. \& Pine, L. (1956). Studies on the growth of species of Actinomyces. J. Bact. $71,47$.

Pope, C. C. \& Stevens, M. F. (1939). The determination of amino-nitrogen using a copper method. Biochem. J. 33, 1070.

Ponteous, J. W. (1960). An electrically heated micro-digestion apparatus. Lab. Pract. $9,795$.

Rosebury, T., Epps, L. J. \& Clark, A. R. (1944). A study of the isolation, cultivation and pathogenicity of Actinomyces israelii recovered from the human mouth and from Actinomycosis in man. J. Infect. Dis. 74, 131.

Thomson, L. \& Lovestedt, S. A. (1951). An Actinomyces-like organism obtained from the human mouth. Proc. Mayo Clin. 26, 169. 